\title{
Phylogenetic Analysis of Crimean-Congo Hemorrhagic Fever Virus in Inner Mongolia, China
}

\author{
Yunyi Kong ${ }^{\mathrm{a}, \mathrm{b}}$, Chao Yan ${ }^{\mathrm{b}}$, Xiaodong Liu ${ }^{\mathrm{b}}$, Lingling Jiang ${ }^{\mathrm{b}}$, Gang Zhang ${ }^{\mathrm{b}}$, Biao He ${ }^{\mathrm{c}}$, Yong Li ${ }^{\mathrm{a}, \mathrm{b}, ~ *}$ \\ ${ }^{a}$ Key Laboratory of Ministry of Education for Protection and Utilization of Special Biological Resources in the Western China, Ningxia \\ University, Yinchuan, 750021, China \\ ${ }^{b}$ School of life science, Ningxia University, Yinchuan, 750021, China \\ ${ }^{c}$ Key Laboratory of Jilin Province for Zoonosis Prevention and Control, Institute of Military Veterinary Medicine, Academy of Military \\ Medical Sciences, Academy of Military Sciences, Changchun, 130062, China
}

\begin{abstract}
Crimean-Congo hemorrhagic fever virus (CCHFV) is a tick-borne arbovirus that can cause bleeding and death in humans. The mortality rate in humans is between 5 to $30 \%$. The pathogen is prevalent in more than 30 countries in the world. In China, reports of strains of CCHFV have been concentrated in Xinjiang province. However, the CCHFV strain has never been reported in Inner Mongolia, China. This study reports new CCHFV strains, HANM-18, from Hyalomma asiaticum and Hyalomma dromedarii collected in Alxa Left Banner and Alxa Right Banner in Inner Mongolia. Complete sequences of CCHFV were obtained by the nested PCR technique and used for analyzing the identity and evolutionary relationship with other CCHFV strains. Interestingly, our results showed that the S and L fragments of the HANM-18 strain had high degrees of identity with Xingjiang isolate strains, and the $\mathrm{M}$ fragment had significant identity with South African isolates. These analyses also indicate that the HANM-18 strain may have been prevalent in northwest Inner Mongolia for many years. This discovery will be helpful in CCHF prevention and control in Inner Mongolia, and it also adds new evidence to the epidemiology of CCHF in China.
\end{abstract}

Keywords: Inner Mongolia; Crimean Congo hemorrhagic fever virus; phylogenetic analysis

\section{Introduction}

Crimean-Congo hemorrhagic fever virus (CCHFV) is a tick-borne single-stranded RNA virus. The virus belongs to the Nairoviridae family of Bunyavirales (Garrison et al., 2020). The genome of CCHFV is composed of three fragments (Garrison et al., 2019). The S segment encodes nucleocapsid proteins, the $\mathrm{M}$ segment encodes two structural glycoproteins ( $\mathrm{Gn}$ and $\mathrm{Gc}$ ), and the $\mathrm{L}$ segment encodes an RNA-dependent RNA polymerase (Deyde et al., 2006; Garrison et al., 2019). As for other segmented RNA viruses, rearrangement is also significant in the evolution and migration of CCHFV. Compared with S and L fragments, the rearrangement of the M fragment is more frequent (Deyde et al., 2006). According to phylogenetic analysis, CCHFV can be divided into seven genetic categories related to geographic origin: two from Asia, two from Europe, and three from Africa (Umair et al., 2020).

CCHF caused by CCHFV is a zoonotic disease. It was first reported in Crimea in 1944, and then found in Congo in 1956, which gives it its name (Bente et al., 2013; Spengler et al., 2019). Most infected people are bitten by ticks carrying the pathogen, while others are infected by contact

\footnotetext{
${ }^{*}$ Corresponding author.

E-mail address: liyong7732@nxu.edu.cn(Y. Li).
} 
with diseased animals or human body fluids (Garrison et al., 2019; Nabeth et al., 2004; Negredo et al., 2019). The clinical symptoms in humans include fever, headache, vomiting, diarrhea, and muscle pain (Ergönül, 2006). In severe cases, there are signs of bleeding and multiple organ dysfunction (Bente et al., 2013; Ergönül, 2006). Ticks (mainly from the genus Hyalomma) are the main vectors of CCHFV; they are not only carriers of the virus, but they are also the natural reservoir of the virus (Spengler et al., 2019; Serretiello et al., 2020). There are no obvious symptoms in mammals infected with CCHFV (Negredo et al., 2019; Spengler et al., 2016). Meanwhile, birds are resistant to CCHFV infection (Negredo et al., 2019). Although some infected animals are usually without infection symptoms, they can still act as hosts in pathogen transmission routes (Serretiello et al., 2020; Spengler et al., 2016; Sorvillo et al., 2020).

The geographical distribution of CCHFV covers most countries and regions in west Asia, the Middle East, Europe, and Africa (Bente et al., 2013; Sorvillo et al., 2020). In China, CCHF infection was first reported in Bachu County of southwest Xinjiang in 1965 (Gao et al., 2010; Wu et al., 2013). Subsequently, there were cases and seropositive reports in the Tarim Basin and surrounding areas (Saijo et al., 2005; Sun et al., 2009). These case reports showed that most of the infected people had close contact with livestock (Gao et al., 2010; Zhang et al., 2018). So far, CCHF cases have only been reported in Xinjiang. However, CCHFV antibodies were detected in livestock and human sera in Qinghai, Inner Mongolia, and Yunnan provinces (Gao et al., 2010; Wu et al., 2013; Xia et al., 2011). This indicates that CCHF may exist in other parts of the Chinese mainland. In previous studies, we reported the detection of CCHFV antibodies in camels and sheep in the Alxa Left Banner and Alxa Right Banner of Inner Mongolia (Li et al., 2020). Nevertheless, the prevalence of CCHFV in this area is not clear. At the same time, the epidemic strain of CCHFV has not been reported in Inner Mongolia.

In this study, we report on the Crimean-Congo hemorrhagic fever virus detected in ticks collected in the Alxa Left Banner and Alxa Right Banner of Inner Mongolia from April to May 2015. The full sequence of the virus was obtained by genome-wide amplification. Phylogenetic analysis and investigation of CCHFV in sheep and camel parasitic ticks were carried out to explore the evolutionary relationship between strains, and the status of local ticks carrying CCHFV was investigated.

\section{Materials and Methods}

\subsection{Sample collection}

On the basis of previous studies, a total of 627 ticks were collected from sheep and camels in the Alxa Left Banner and Alxa Right Banner of Inner Mongolia, China, from April to May 2015 (Figure 1) (Li et al., 2020). For each sampling site, three flocks of sheep or camels were selected, and more than 50 animals in each flock were randomly selected for sampling. Ticks found on the skin surface of the animals were removed and collected in a container. The ticks were initially identified to species by morphological characteristics, and then the species were confirmed based on PCR amplification and sequencing of the cytochrome c oxidase subunit 1 gene (Zahler and Gothe, 1997; Apanaskevich and Horak, 2010; Gou et al., 2018). All samples were frozen and stored at $-80{ }^{\circ} \mathrm{C}$. The collected ticks were pooled according to the hosts they were collected from and the tick species . Herdsmen were orally informed about the aims and process of this study. All animal owners agreed and allowed us to collect ticks from their camels or sheep. 


\subsection{Sample Processing and RNA Extraction}

12-15 ticks were pooled in one sample based on the species and life stage for processing and analysis. To prepare samples, ticks from each pool were put into a $2 \mathrm{~mL}$ centrifuge tube containing $1 \mathrm{~mL}$ of Dulbecco's modified Eagle's medium (DMEM; Gibco, Carlsbad, CA, USA) prior to being homogenized in a frozen grinder (Jingxin, Shanghai, China). The homogenized samples were then centrifuged at $4{ }^{\circ} \mathrm{C}$ and $12,000 \times \mathrm{g}$ for $10 \mathrm{~min}$. The supernatants were collected and stored at $-80^{\circ} \mathrm{C}$. Total RNA was extracted from each tick pool with the RNeasy Mini Kit (QIAGEN, Hiden, Germany). According to the manufacturer's instructions, cDNA was synthesized using M-MLV reverse transcriptase (TaKaRa Biotechnology, Dalian, China). In brief, $0.5 \mu \mathrm{L}$ dNTP mixture, $1 \mu \mathrm{L}$ Oligo (dT) 18 primer, $1 \mu \mathrm{L}$ template RNA $(100 \mathrm{ng} / \mu \mathrm{L})$, and $5 \mu \mathrm{L}$ RNase-free water were mixed and incubated at $65{ }^{\circ} \mathrm{C}$ for $5 \mathrm{~min}$. Next, $2 \mu \mathrm{L} 5 \mathrm{x}$ reverse transcriptase M-MLV Buffer, $0.25 \mu \mathrm{L}$ RNase inhibitor $(40 \mathrm{U} / \mu \mathrm{L})$, and reverse transcriptase $\mathrm{M}-\mathrm{MLV}(200 \mathrm{U} / \mu \mathrm{L})$ were added to the tube, sequentially incubated at $42{ }^{\circ} \mathrm{C}$ for $1 \mathrm{~h}$, and then at $70{ }^{\circ} \mathrm{C}$ for $15 \mathrm{~min}$. The cDNA was then stored at $-40{ }^{\circ} \mathrm{C}$.

\subsection{CCHFV detection and whole-genome amplification}

To detect whether CCHFV was present in the tick pools, part of the $\mathrm{S}$ fragment was amplified by specific nested PCR for detection. The PCR reaction system was a $50 \mu \mathrm{L}$ mixture, including 25 $\mu \mathrm{L} 2 \mathrm{x}$ Taq PCR master mix, $2 \mu \mathrm{L}$ template cDNA, $19 \mu \mathrm{L} \mathrm{ddH}_{2} \mathrm{O}$ and 20 pmol of each forward and reverse primer. For the first round of PCR, a pair of primers (CCHFV-F 5'TGGACACYTTCACAAACTC-3', CCHFV-R 5'- GRYRAAYTCCCTRCACCA-3') was used to amplify a 536 bp fragment. The PCR amplification was performed in a power cycler (Analytikjena, Jena, Germany) using the following procedure: pre-denaturation at $94{ }^{\circ} \mathrm{C}$ for $3 \mathrm{~min}$, then denaturation at $94{ }^{\circ} \mathrm{C}$ for $30 \mathrm{~s}$, annealing at $54{ }^{\circ} \mathrm{C}$ for $40 \mathrm{~s}$, and extension at $72{ }^{\circ} \mathrm{C}$ for $40 \mathrm{~s}$. This cycle was repeated for a total of 35 cycles, followed finally by maintaining at $72{ }^{\circ} \mathrm{C}$ for $7 \mathrm{~min}$. For the second round of PCR, another pair of primers (CCHFV-F' 5'- GAATGTGCATGGGTTAGCTC3', CCHFV-R' 5'- GACATCACAATTTCACCAGG-3') was used to amplify a 260 bp fragment. The amplification was performed using the following program: pre-denaturation at $94{ }^{\circ} \mathrm{C}$ for $3 \mathrm{~min}$, denaturation at $94{ }^{\circ} \mathrm{C}$ for $30 \mathrm{~s}$, annealing at $54^{\circ} \mathrm{C}$ for $40 \mathrm{~s}$ and extension at $72{ }^{\circ} \mathrm{C}$ for $30 \mathrm{~s}$. This cycle was repeated for a total of 35 cycles, followed finally by holding at $72{ }^{\circ} \mathrm{C}$ for $7 \mathrm{~min}$. The PCR products were analyzed by agarose nucleic acid gel electrophoresis and sent to ComateBio (Changchun, China) for Sanger sequencing.

Genomic amplification was carried out in tick pools where CCHFV was detected. The semi-nested PCR primers (Table S1) were designed to amplify the whole genome sequence of CCHFV. The full sequences were amplified by LA Taq DNA polymerase (TaKaRa Biotechnology, Dalian, China) under the following conditions: pre-denaturation at $94{ }^{\circ} \mathrm{C}$ for $1 \mathrm{~min}$, then denaturation at $98^{\circ} \mathrm{C}$ for $10 \mathrm{~s}$, annealing at $55^{\circ} \mathrm{C}$ for $30 \mathrm{~s}$, and extension at $72{ }^{\circ} \mathrm{C}$ for $30-90 \mathrm{~s}$. This cycle was repeated for a total of 35 cycles, followed finally by holding at $72{ }^{\circ} \mathrm{C}$ for $10 \mathrm{~min}$.

\subsection{Phylogenetic analysis}

Viral sequences were assembled and aligned using Clustal W and compared with the sequences of other CCHFV strains in GenBank (Thompson et al., 2003). Respectively, the best-fit models (the Kimura 2-parameter model and the JTT matrix-based model) of nucleotide and amino acid sequence evolution were estimated using MEGA 7.0 (Kimura 1980; Jones et al., 1992; Kumar et al., 2016). 
Phylogenetic trees were constructed using the maximum-likelihood method by MEGA 7.0 software (http://www.megasoftware.net/). The reliability of the branches of the tree was assessed using a bootstrap analysis with 1000 replicates. The phylogenetic trees were edited and visualized with FigTree v.1.4.4 (http://tree.bio.ed.ac.uk/software/figtree). The MegAlign program implemented in the Lasergene software package v5.0 (DNAstar, Madison, WI, USA) was used to calculate the identity between nucleic acid and amino acid sequences.

\subsection{Data analysis}

The positive rate was determined by calculating the minimum infection rate (MIR), which was the ratio of the number of positive tick pools to the total number of analyzed ticks (Walter et al., 1980).

\section{Results}

\subsection{Detection of CCHFV in Ticks}

According to the tick species, sampling site, and host animal species, 73 ticks (divided into five tick pools) were collected in Alxa Left Banner, and 554 ticks (divided into 36 tick pools) were collected in Alxa Right Banner (Table 1). Nested PCR was used to test for presence of CCHFV in these 41 tick pools. By PCR amplification, CCHFV was detected in only one tick pool in Alxa Left Banner, consisting of Hyalomma asiaticum. The minimum infection rate (MIR) of CCHFV was $2.2 \%$ in Alxa Left Banner. Meanwhile, CCHFV was detected in one-sixth of the tick pools in Alxa Right Banner, including four $H$. asiaticum pools and two Hyalomma dromedarii pools. In this area, the MIRs of CCHFV were $1.2 \%$ and $1.1 \%$, respectively (Table 1). CCHFV was not detected in Dermacentor marginatus from Alxa Left Banner or Dermacentor nuttalli from Alxa Right Banner.

\subsection{Homology and Phylogeny Analysis}

The new strain of CCHFV genome which was a genetic sequence recovered from tick pools, named HANM-18, consisted of three fragments: S (1,672 nt), M (5,368 nt), and L (12,155 nt) (Genbank Accession Numbers: MN832721-MN832723). Phylogenetic analysis of the HANM-18 strain showed that there were three complete sequences.

\subsection{1 $\mathrm{S}$ fragment phylogenetic analysis}

According to their geographical distribution, $\mathrm{S}$ fragments were divided into eight genotypes, namely Asia 1 and 2, Africa 1-3, and Europe 1-3 (Guo et al., 2017). The typing of M and L fragments was described previously (Deyde et al., 2006; Morikawa et al., 2007; Carroll et al., 2010). Most of the previously reported Chinese strains were clustered in the Asia 2 group, while WJQ16206 and FK16116 were clustered in Asia 1 (Zhang et al., 2018). In this study, HANM-18 and Chinese isolates were clustered into the Asia 2 group. According to Figure 2A, the evolutionary relationship between HANM-18 and the currently reported Chinese isolates shows that they have the same ancestral strain, while the evolutionary relationship between HANM-18 and the ancestral strains seems to be closer. In the homologous relationship, table S2 shows that the $\mathrm{S}$ fragment of the HANM-18 strain in this study had the highest identity with the CCHFV isolate in Xinjiang, China, ranging from $95.5-96.6 \%$. Among these strains, HANM-18 had the highest nucleic acid identity with CCHFV discovered in Xinjiang in the 1960s and 1970s. 


\subsection{2 $\mathrm{M}$ fragment phylogenetic analysis}

As for the $\mathrm{M}$ tree, it showed a different evolution from the currently reported Chinese strains. The M fragment of HANM-18 was clustered with an isolate from South Africa (Figure 2B). The Chinese CCHFV strains demonstrated different aggregation phenomena on the phylogenetic tree. The identity between the HANM-18 strain and South African strains (SPU97/85, SPU415/85, and SPU556/87) was $91.1 \%$ (Table S3). The homology of HANM-18 with South African strains such as SPU103/87, SPU187/90, SPU48/90, SPU130/89, SPU44/08, and SPU431/85 ranged from $80.8 \%$ $-90.8 \%$. The identity with some strains $(8402,88166$, BA8402, BA88166, and C-68031) from Xinjiang in China was $87 \%$, and the identity with the Oman strain was $86 \%$. Compared with the amino acid sequence identity of the $\mathrm{M}$ fragment, it was observed that the amino acid identity of HANM-18 and South Africa was the highest, which was 91.8-91.9\% (Table S3). Simultaneously, the identity with some Chinese isolates, Oman strains, and Pakistani strains was over $89 \%$. To further determine the evolutionary relationship of the M fragment in the HANM-18 strain, the sequences with more than $85 \%$ amino acid identity were selected to construct the ML phylogenetic tree. In this amino acid tree, the HANM-18 strain was also clustered with South African isolates, and HANM-18 had a distant genetic relationship with Chinese isolates (Figure 3).

\subsubsection{L fragment phylogenetic analysis}

In the L tree, the strain was clustered with YL04057 and 79121M18, discovered in China in 2004, and YL16070 and YL16204 discovered in 2016 (Figure 2C). However, it was far away from the C-68031 strain discovered in 1968. The homology of HANM-18 with YL04057, 79121M18, YL16070, and YL16204 was the highest (93.7\%), while that with c-68031 was 87.5\% (table S3).

\section{Discussion}

Crimean-Congo hemorrhagic fever virus is a tick-borne virus in many countries in Asia, Africa, and Europe. In China, CCHFV is mainly distributed in Xinjiang province, and no cases have been reported in other provinces. In order to investigate the distribution of CCHFV in northwestern China, ticks were collected and tested in the western region of Inner Mongolia adjacent to Xinjiang.

In the current study, all ticks found to carry CCHFV were of the Hyalomma genus. Hyalomma asiaticum has been confirmed to be the main vector of CCHFV in Xinjiang, China (Guo et al., 2017; Moming et al., 2018). Hyalomma dromedarii, as a tick species mainly parasitic to camels, has also been demonstrated to carry CCHFV and infect the host (Camp et al., 2020; Moshaverinia and Moghaddas 2015). Strangely enough, H. dromedarii was found in both Left and Right Banner, while CCHFV was detected only in $H$. dromedarii of females from Alxa Right Banner. In the previous CCHFV survey in Saudi Arabia, CCHFV was also detected in H. dromedarii of females (Camp et al., 2020).

The identity and phylogeny analysis of CCHFV demonstrated that CCHFV, as a segmented RNA virus, showed high genetic diversity (Deyde et al., 2006). In the phylogenetic tree of $\mathrm{S}$ fragments, the isolates of HANM-18 from Xinjiang were grouped into Asia 2, and China is the origin of Asia 2 (Figure 2A) (Mild et al., 2010). And the homology with the previously reported strains in Xinjiang were the highest (Table S2).For the L fragment, the homology of HANM-18 with some Xinjiang strains (YL04057, 79121M18, YL16070, and YL16204) were the highest. HANM18 was clustered with the Xinjiang strains in Asia 3 group on the L tree (Figure 2C). It is far away from some strains found in the Middle East. For the M fragment, HANM-18 was clustered with 
strains from South Africa (SPU97/85, SPU415/85, SPU556/87, and SPU556/87), but is far away from Chinese isolates (Figure 2B,). The identity between HANM-18 and South African strains is also the highest. The amino acid tree of the $\mathrm{M}$ fragment and amino acid identity analysis also reached the same conclusion (Figure 3).

For CCHFV, due to its wide geographical distribution, there are significant differences among different epidemic areas, and the variation in different fragments is also dissimilar: from 10-20\% for the S segment to 31\% of the M segment (Deyde et al., 2006; Bente et al., 2013; Carroll et al., 2010). In general, the $S$ segment is the slowest and most conserved, followed by the $L$ segment, while the M segment shows great differences (Bente et al., 2013; Morikawa et al., 2007). The M fragment of HANM-18 is highly homologous with the South African isolate and is closer to the ancestor of the South African isolate in the genetic relationship (Figure S1B). This suggests that the M fragment of HANM-18 may be from an older strain. Then, its geographical isolation in China was characterized, and adaptive evolution occurred in the process of transmission. There are big differences compared with the strains prevalent in South Africa. At the same time, HANM-18 was far away from the Xinjiang strain in the phylogenetic tree (Figure S1B). This indicates that there are different epidemic types of the CCHFV M fragment in China. The reason for this phenomenon is not only mutation, but also rearrangement between different strains (Varsani et al., 2018). The S, M, and L fragments of CCHFV showed different prevalence and aggregation in China, which indicated that rearrangement was also common and played an important role in the transmission and evolution of CCHFV (Zhou et al., 2013). In previous reports, the South African isolate spu415/85 was closely related to Asian rearrangement (Goedhals et al., 2014). The strains found in South Africa have been confirmed to be prevalent and distributed in China (Zhou et al., 2013; Goedhals et al., 2014). There are many reasons for these rearrangements, either because migratory birds have carried the virus to different places, or because of the trade activities of livestock; ticks parasitized on these livestock have been taken to all parts of the world (Deyde et al., 2006; Serretiello et al., 2020; Spengler et al., 2016; Mild et al., 2010; Zhou et al., 2013; Palomar et al., 2013; Mancuso et al., 2019). In addition, the evolutionary relationship of the M fragment in the CCHFV strain found in Mongolia showed the same phenomenon as that of HANM-18 during the last 13-14 years (Voorhees et al., 2018). Inner Mongolia borders Mongolia, and it is possible that the CCHFV strain will spread between the two regions with the migration of birds or wild animals. However, since the data have not been published, it is impossible to make more comparisons.

In summary, this study indicates the presence of CCHFV strains in Inner Mongolia in China. The genetic relationship is not only related to the strains isolated from Xinjiang, but also shows that there are different types of CCHFV in China. This is the first time that CCHFV strains have been found and reported outside Xinjiang in China, which provides a good reference to characterize the prevalence and migration of CCHFV in China and Asia.

\section{Conclusions}

The present study provides data on the prevalence of important zoonotic agents in ticks from sheep and camels in Inner Mongolia of China. This novel information will be useful not only for medical and veterinary practitioners, but also the public health officials, when assessing the risks associated with tick-borne zoonoses in China. In addition, the authors hope that this report will also contribute, to increasing an overall awareness of tick-borne diseases among the population of China. 


\section{Funding source}

This work was supported by the National Natural Science Foundation of China (No. 31760736).

\section{CRediT authorship contribution statement}

Yunyi Kong: Methodology, Investigation, Data curation, Formal analysis, Writing-original draft. Chao Yan: Methodology, Investigation, Data curation. Dongxiao Liu: Investigation, Data curation. Lingling Jiang: Methodology, Investigation. Gang Zhang: Investigation, Data curation. Biao He: Formal analysis, Resources. Yong Li: Project administration, Conceptualization, Supervision, Writing - review \& editing.

\section{Declaration of Competing Interest}

The authors do not have any conflicts of interest to report.

\section{Acknowledgements}

This work was supported by Ningxia University (China) and the Academy of Military Medical Sciences (China). We thank Zhizhou Tan for his expert technical assistance.

\section{Animal and Human Right Statement}

The experiments involving sheep and camels were performed according to protocols approved by the Institutional Animal Care and Use Committee of Ningxia University (NXU-2019007). The need for consent is deemed unnecessary according to national regulations, but an informed verbal consent was obtained from the sheep and camel owners. The ethics committee for the use of animals of Ningxia University approved this study.

\section{Appendix A. Supplementary data}

Table S1-S4

\section{References}

Garrison, A.R., Alkhovsky, S. V., Avšič-Županc, T., Bente D.A., Bergeron, É., Burt, F., Di Paola N., Ergunay K., Hewson R., Kuhn J.H. and others, 2020. ICTV virus taxonomy profile: Nairoviridae. J. Gen. Virol. 101, 798-799.

Garrison, A.R., Smith D.R., Golden J.W., 2019. Animal models for Crimean-Congo hemorrhagic fever human disease. Viruses 11, 590.

Deyde, V.M., Khristova M.L., Rollin P.E., Ksiazek T.G., Nichol S.T., 2006. Crimean-Congo hemorrhagic fever virus genomics and global diversity. J. Virol. 80:8834-42.

Umair, M., Khurshid A., Alam M.M., Akhtar R., Salman M., Ikram A., 2020. Genetic diversity and phylogenetic analysis of Crimean-Congo hemorrhagic fever viruses circulating in Pakistan during 2019. PLoS Negl Trop Dis. 14, e0008238.

Bente, D.A., Forrester N.L., Watts D.M., McAuley A.J., Whitehouse C.A., Bray M., 2013. Crimean-Congo 
hemorrhagic fever: history, epidemiology, pathogenesis, clinical syndrome and genetic diversity. Antiviral Res. 100, 159-89.

Spengler, J.R., Bergeron E., Spiropoulou C.F., 2019. Crimean-Congo hemorrhagic fever and expansion from endemic regions. Curr. Opin. Virol. 34, 70-78.

Nabeth, P., Cheikh D.O., Lo B., Faye O., Vall I.O., Niang M., Wague B., Diop D., Diallo M., Diallo B. and others, 2004. Crimean-Congo hemorrhagic fever, Mauritania. Emerg Infect Dis. 10:2143-9.

Negredo, A., Habela M.A., Ramirez de Arellano E., Diez F., Lasala F., Lopez P., Sarria A., Labiod N., Calero-Bernal R., Arenas M. and others, 2019. Survey of Crimean-Congo Hemorrhagic fever enzootic focus, Spain, 2011-2015. Emerg Infect Dis. 25, 1177-1184.

Ergönül, Ö., 2006. Crimean-Congo haemorrhagic fever. The Lancet Infectious Diseases. 6, 203-214.

Serretiello, E., Astorri R., Chianese A., Stelitano D., Zannella C., Folliero V., Santella B., Galdiero M., Franci G., Galdiero M., 2020. The emerging tick-borne Crimean-Congo haemorrhagic fever virus: A narrative review. Travel Med Infect Dis. 37, 101871.

Spengler, J.R., Estrada-Pena A., Garrison A.R., Schmaljohn C., Spiropoulou C.F., Bergeron E., Bente D.A., 2016. A chronological review of experimental infection studies of the role of wild animals and livestock in the maintenance and transmission of Crimean-Congo hemorrhagic fever virus. Antiviral Res. 135, 31-47.

Sorvillo, T.E., Rodriguez S.E., Hudson P., Carey M., Rodriguez L.L., Spiropoulou C.F., Bird B.H., Spengler J.R., Bente D.A., 2020. Towards a sustainable one health approach to Crimean-Congo hemorrhagic fever prevention: focus areas and gaps in knowledge. Trop Med Infect Dis. 5, 113.

Gao, X., Nasci R., Liang G., 2010. The neglected arboviral infections in mainland China. PLoS Negl Trop Dis. 4, e624.

Wu, X.B., Na R.H., Wei S.S., Zhu J.S., Peng H.J., 2013. Distribution of tick-borne diseases in China. Parasit Vectors. 6,119 .

Saijo, M., Tang Q., Shimayi B., Han L., Zhang Y., Asiguma M., Tianshu D., Maeda A., Kurane I., Morikawa S., 2005. Recombinant nucleoprotein-based serological diagnosis of Crimean-Congo hemorrhagic fever virus infections. J. Med. Virol. 75, 295-9.

Sun, S., Dai X., Aishan M., Wang X., Meng W., Feng C., Zhang F., Hang C., Hu Z., Zhang Y., 2009. Epidemiology and phylogenetic analysis of crimean-congo hemorrhagic fever viruses in xinjiang, china. J. Clin. Microbiol. 47, 2536-43.

Zhang, Y., Shen S., Fang Y., Liu J., Su Z., Liang J., Zhang Z., Wu Q., Wang C., Abudurexiti A. and others, 2018. Isolation, Characterization, and Phylogenetic Analysis of Two New Crimean-Congo Hemorrhagic Fever Virus Strains from the Northern Region of Xinjiang Province, China. Virol. Sin. 33, 74-86.

Zahler, M., Gothe, R., 1997. Evidence for the reproductive isolation of Dermacentor marginatus and Dermacentor reticulatus (Acari: Ixodidae) ticks based on cross-breeding, morphology and molecular studies. Experimental \& applied acarology. 21, 685-696.

Apanaskevich, D. A., Horak I.G., 2010. The genus Hyalomma. XI. Redescription of all parasitic stages of H. (Euhyalomma) asiaticum (Acari: Ixodidae) and notes on its biology. Exp Appl Acarol. 52, 207-20.

Xia, H., Li P., Yang J., Pan L., Zhao J., Wang Z., Li Y., Zhou H., Dong Y., Guo S. and others, 2011. Epidemiological survey of Crimean-Congo hemorrhagic fever virus in Yunnan, China, 2008. Int. J. Infect. Dis. 15, e45963.

Li, Y., Yan C., Liu D., He B., Tu C., 2020. Seroepidemiological Investigation of Crimean-Congo Hemorrhagic Fever Virus in Sheep and Camels of Inner Mongolia of China. Vector Borne Zoonotic Dis. 20, 461-467.

Gou, H., Xue H., Yin H., Luo J., Sun X., 2018. Molecular Characterization of Hard Ticks by Cytochrome c Oxidase Subunit 1 Sequences. Korean J Parasitol. 56, 583-588. 
Thompson, J.D., Gibson T.J., Higgins D.G., 2003. Multiple sequence alignment using ClustalW and ClustalX. Current protocols in bioinformatics. 2.3. 1-2.3. 22 .

Kimura, M., 1980. A simple method for estimating evolutionary rates of base substitutions through comparative studies of nucleotide sequences. Journal of molecular evolution. 16, 111-120.

Jones, D.T., Taylor W.R., Thornton J.M., 1992. The rapid generation of mutation data matrices from protein sequences. Comput Appl Biosci. 8, 275-82.

Kumar, S., Stecher G., Tamura K., 2016. MEGA7: Molecular Evolutionary Genetics Analysis Version 7.0 for Bigger Datasets. Mol. Biol. Evol. 33, 1870-4.

Walter, S.D., Hildreth S.W., Beaty B.J., 1980. Estimation of infection rates in populations of organisms using pools of variable size. American Journal of Epidemiology. 112, 124-128.

Guo, R., Shen S., Zhang Y., Shi J., Su Z., Liu D., Liu J., Yang J., Wang Q., Hu Z. and others, 2017. A new strain of Crimean-Congo hemorrhagic fever virus isolated from Xinjiang, China. Virol Sin. 32:80-88.

Morikawa, S., Saijo M., Kurane I., 2007. Recent progress in molecular biology of Crimean-Congo hemorrhagic fever. Comp Immunol Microbiol Infect Dis. 30, 375-89.

Carroll, S.A., Bird B.H., Rollin P.E., Nichol S.T., 2010. Ancient common ancestry of Crimean-Congo hemorrhagic fever virus. Mol Phylogenet Evol. 55, 1103-10.

Kar, S., Rodriguez S.E., Akyildiz G., Cajimat M.N.B., Bircan R., Mears M.C., Bente D.A., Keles A.G., 2020. Crimean-Congo hemorrhagic fever virus in tortoises and Hyalomma aegyptium ticks in East Thrace, Turkey: potential of a cryptic transmission cycle. Parasit Vectors. 13, 201.

Moming, A., Yue X., Shen S., Chang C., Wang C., Luo T., Zhang Y., Guo R., Hu Z., Zhang Y. and others, 2018. Prevalence and phylogenetic analysis of Crimean-Congo hemorrhagic fever virus in ticks from different ecosystems in Xinjiang, China. Virol. Sin. 33, 67-73.

Palomar, A.M., Portillo A., Mazuelas D., Roncero L., Arizaga J., Crespo A., Gutierrez O., Marquez F.J., Cuadrado J.F., Eiros J.M. and others, 2016. Molecular analysis of Crimean-Congo hemorrhagic fever virus and Rickettsia in Hyalomma marginatum ticks removed from patients (Spain) and birds (Spain and Morocco), 2009-2015. Ticks Tick Borne Dis. 7, 983-987.

Camp, J.V., Kannan D.O., Osman B.M., Shah M.S., Howarth B., Khafaga T., Weidinger P., Karuvantevida N., Kolodziejek J., Mazrooei H. and others, 2020. Crimean-Congo Hemorrhagic Fever Virus Endemicity in United Arab Emirates, 2019. Emerg Infect Dis. 26, 1019-1021.

Moshaverinia, A., Moghaddas E., 2015. Prevalence of tick infestation in dromedary camels (Camelus dromedarius) brought for slaughter in Mashhad abattoir, Iran. J Parasit Dis. 39, 452-5.

Apanaskevich, D.A., Schuster A.L., Horak I.G., 2008. The genus Hyalomma: VII. Redescription of all parasitic stages of H. (Euhyalomma) dromedarii and H. (E.) schulzei (Acari : Ixodidae). Journal of Medical Entomology. 45, 817-831.

Mild, M., Simon M., Albert J., Mirazimi A., 2010. Towards an understanding of the migration of Crimean-Congo hemorrhagic fever virus. J. Gen. Virol. 91, 199-207.

Varsani, A., Lefeuvre P., Roumagnac P., Martin D., 2018. Notes on recombination and reassortment in multipartite/segmented viruses. Curr. Opin. Virol. 33:156-166.

Zhou, Z., Deng F., Han N., Wang H., Sun S., Zhang Y., Hu Z., Rayner S., 2013. Reassortment and migration analysis of Crimean-Congo haemorrhagic fever virus. J. Gen. Virol. 94, 2536-2548.

Goedhals, D., Bester P.A., Paweska J.T., Swanepoel R., Burt F.J., 2014. Next-generation sequencing of southern African Crimean-Congo haemorrhagic fever virus isolates reveals a high frequency of $M$ segment reassortment. Epidemiol Infect. 142, 1952-62.

Palomar, A.M., Portillo A., Santibanez P., Mazuelas D., Arizaga J., Crespo A., Gutierrez O., Cuadrado J.F., Oteo J.A., 
bioRxiv preprint doi: https://doi.org/10.1101/2021.06.06.447231; this version posted June 7, 2021. The copyright holder for this preprint (which was not certified by peer review) is the author/funder. All rights reserved. No reuse allowed without permission.

2013. Crimean-Congo hemorrhagic fever virus in ticks from migratory birds, Morocco. Emerg Infect Dis.

19, 260-3.

Mancuso, E., Toma L., Polci A., d'Alessio S.G., Di Luca M., Orsini M., Di Domenico M., Marcacci M., Mancini G., Spina F. and others, 2019. Crimean-Congo Hemorrhagic Fever Virus Genome in Tick from Migratory Bird, Italy. Emerg Infect Dis. 25, 1418-1420.

Voorhees, M.A., Padilla S.L., Jamsransuren D., Koehler J.W., Delp K.L., Adiyadorj D., Baasandagwa U., Jigjav B., Olschner S.P., Minogue T.D. and others, 2018. Crimean-Congo Hemorrhagic Fever Virus, Mongolia, 2013-2014. Emerg Infect Dis. 24, 2202-2209.

Table 1. Molecular detection of CCHFV from ticks isolated from different regions in Inner Mongolia, China

\begin{tabular}{|c|c|c|c|c|c|c|c|}
\hline $\begin{array}{c}\text { Areas of } \\
\text { Sampling }\end{array}$ & $\begin{array}{c}\text { Host } \\
\text { species }\end{array}$ & Tick species & $\begin{array}{c}\text { Tick life } \\
\text { stage }\end{array}$ & $\begin{array}{c}\text { Number of } \\
\text { ticks }\end{array}$ & $\begin{array}{l}\text { Number } \\
\text { of pools }\end{array}$ & Number of positive pools & Positive rate $(\%)$ \\
\hline \multirow{3}{*}{$\begin{array}{l}\text { Alxa Left } \\
\text { Banner }\end{array}$} & \multirow{3}{*}{ Sheep } & $\begin{array}{l}\text { Hyalomma } \\
\text { asiaticum }\end{array}$ & $\begin{array}{c}\text { Adult } \\
\text { (Female) }\end{array}$ & 45 & 3 & 1 & 2.2 \\
\hline & & $\begin{array}{l}\text { Hyalomma } \\
\text { dromedarii }\end{array}$ & $\begin{array}{l}\text { Adult } \\
\text { (Male) }\end{array}$ & 13 & 1 & 0 & 0 \\
\hline & & $\begin{array}{c}\text { Dermacentor } \\
\text { marginatus }\end{array}$ & Nymph & 15 & 1 & 0 & 0 \\
\hline \multirow{3}{*}{$\begin{array}{l}\text { Alxa Right } \\
\text { Banner }\end{array}$} & \multirow{3}{*}{ Camel } & $\begin{array}{c}\text { Hyalomma } \\
\text { asiaticum }\end{array}$ & $\begin{array}{c}\text { Adult } \\
\text { (Female) }\end{array}$ & 336 & 22 & 4 & 1.2 \\
\hline & & $\begin{array}{l}\text { Hyalomma } \\
\text { dromedarii }\end{array}$ & $\begin{array}{c}\text { Adult } \\
\text { (Female) }\end{array}$ & 187 & 12 & 2 & 1.1 \\
\hline & & $\begin{array}{c}\text { Dermacentor } \\
\text { nuttalli }\end{array}$ & Nymph & 31 & 2 & 0 & 0 \\
\hline
\end{tabular}

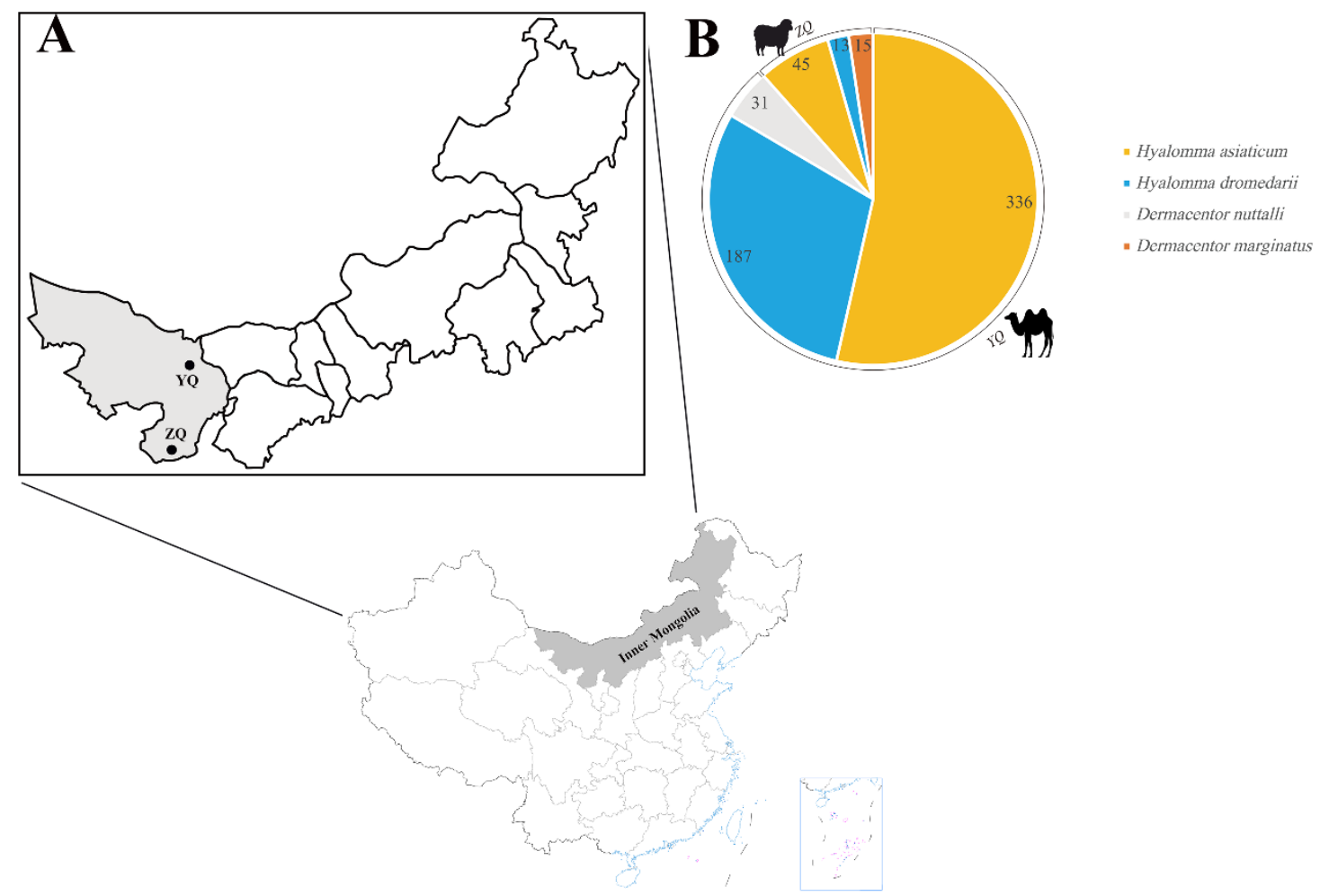


Figure 1. Information for ticks included in the study. (A) Sampling locations; (B) tick species composition, quantity, and host animals. ZQ: Alxa Left Banner, YQ: Alxa Right Banner. 


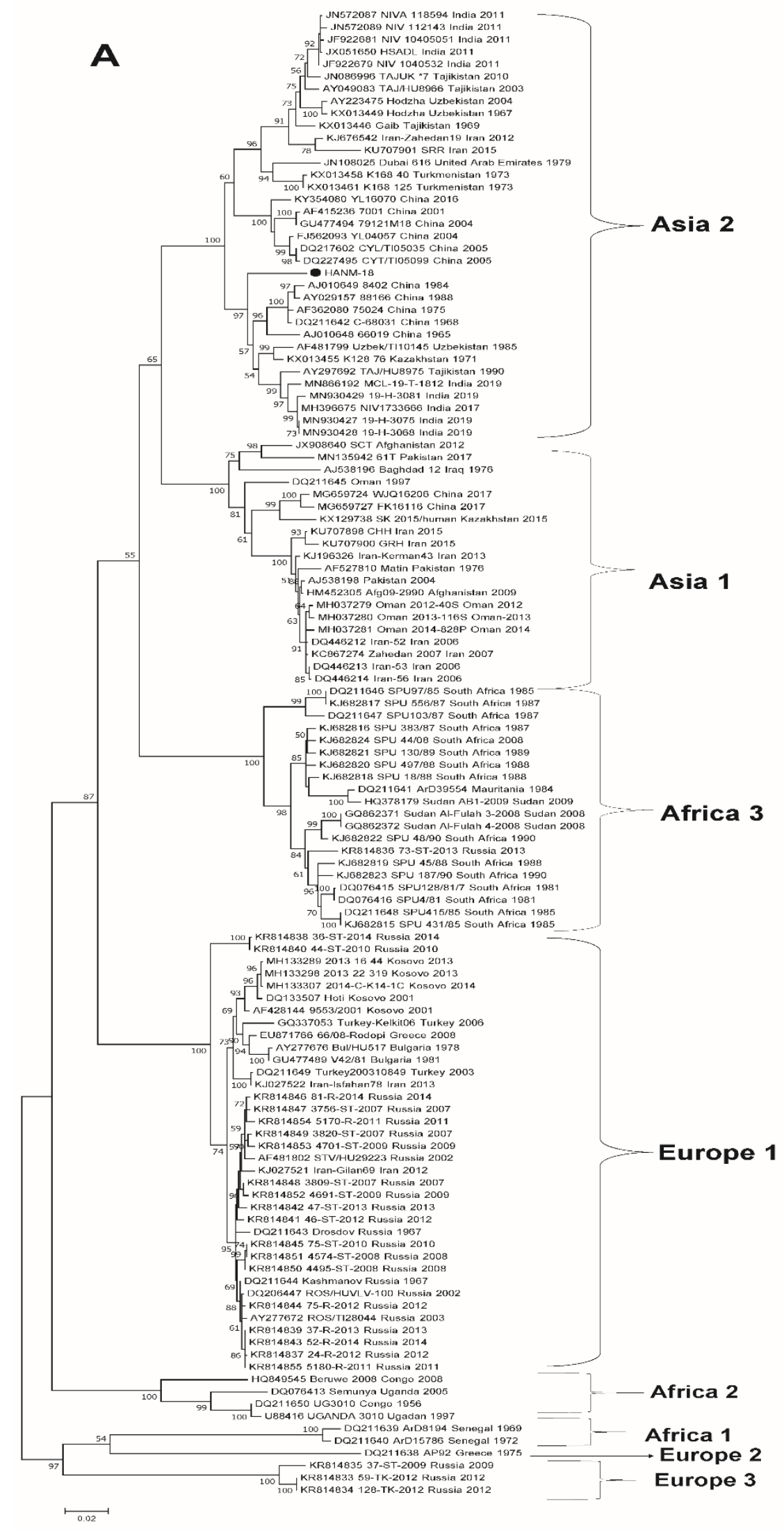




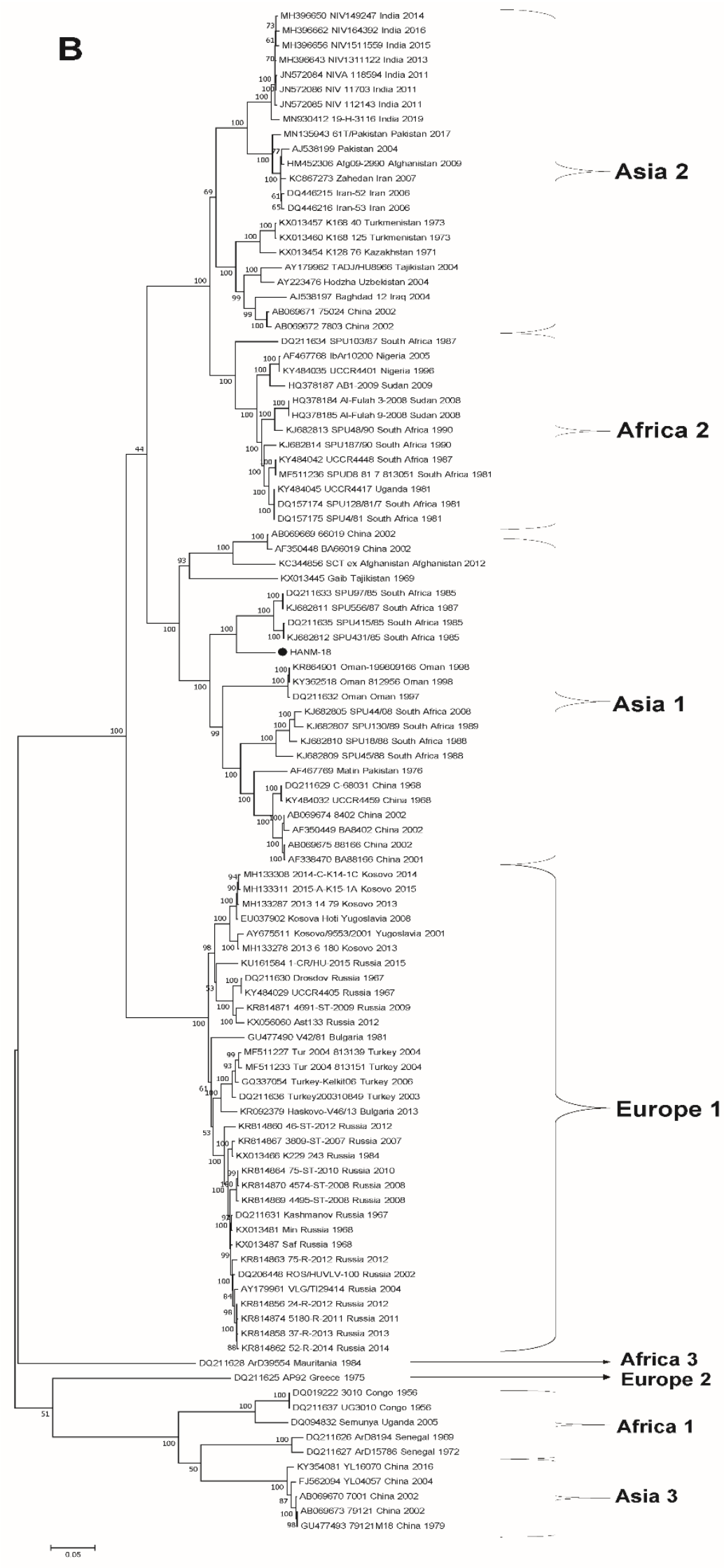




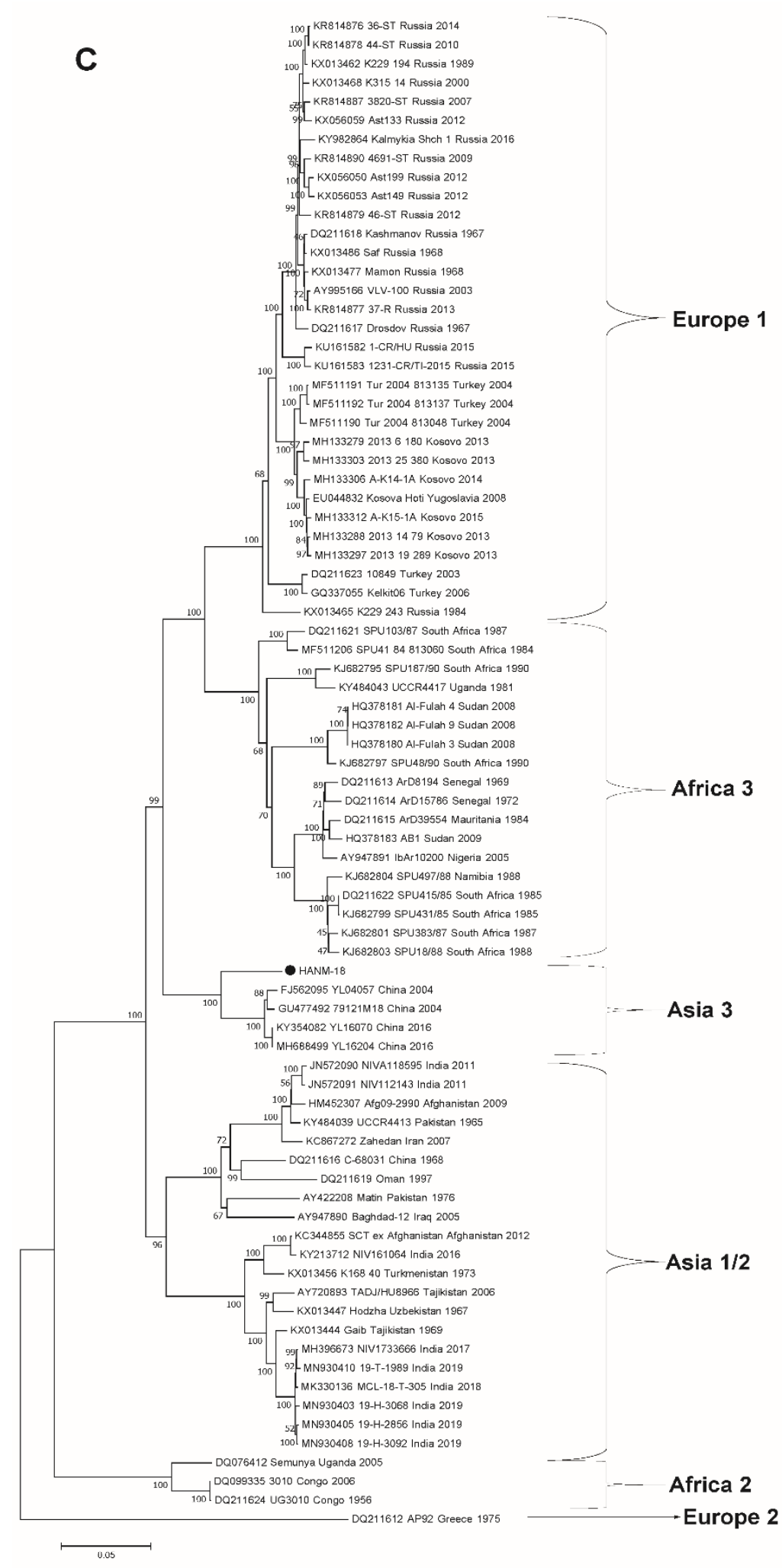

Figure 2. Maximum likelihood trees of Crimean-Congo hemorrhagic fever virus strains based on the complete sequences of the $\mathrm{S}(\mathbf{A}), \mathrm{M}(\mathbf{B})$, and L (C) segments. The solid triangles represent the same type of strains, and the hollow triangles represent the strains of the same country. The size of the triangle has nothing to do with the number of substituting strains. The new strain in this study is highlighted with a black solid circle. 


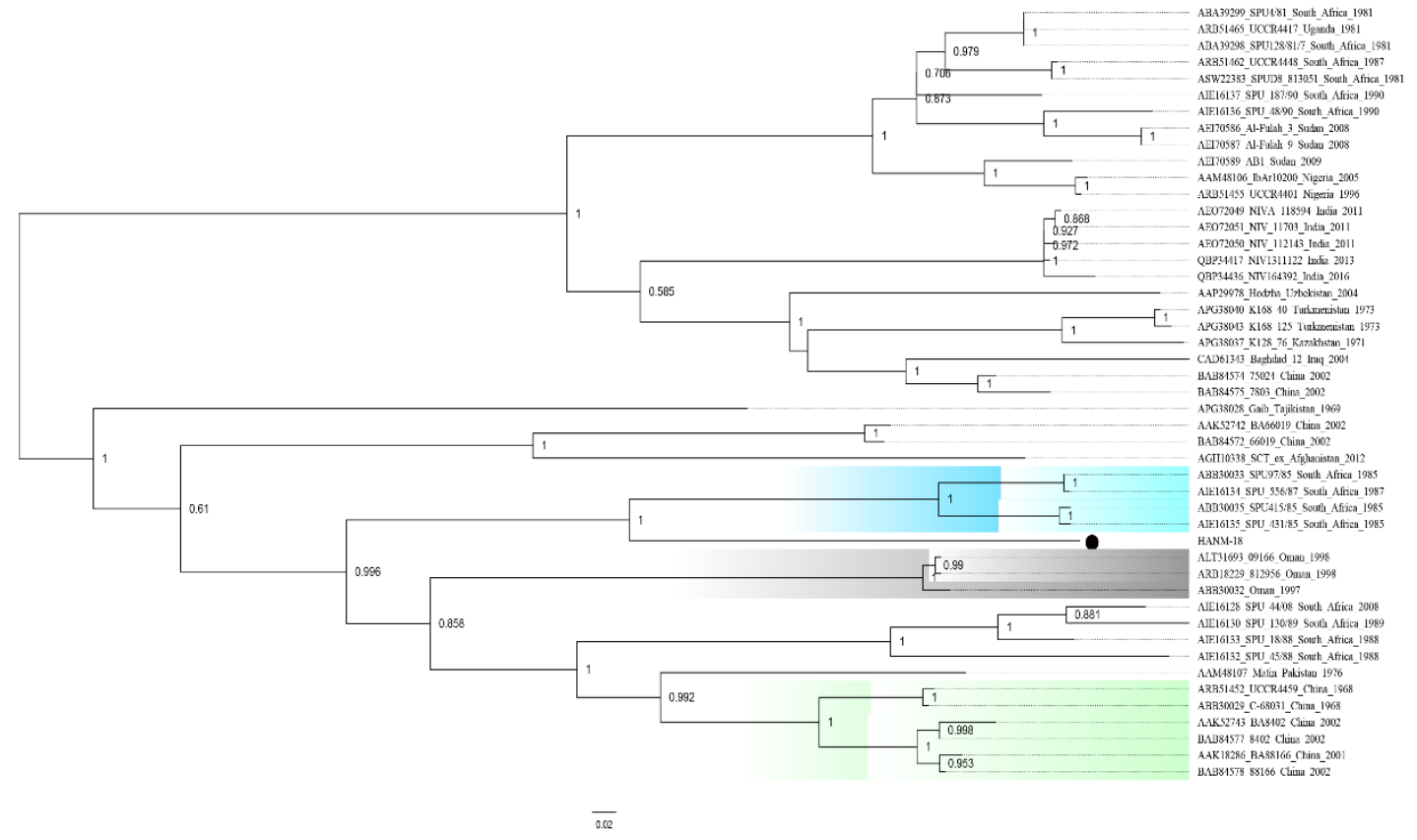

Figure 3. A phylogenetic tree for Crimean-Congo hemorrhagic fever virus based on the glycoprotein precursor was constructed using the maximum likelihood method. The blue, gray, and green areas are used to represent the strains from South Africa, Oman, and China. The new strain in this study is highlighted with a black solid circle. 
Table S1. Primer used in the CCHFV whole-genome amplification

\begin{tabular}{|c|c|c|}
\hline \multicolumn{3}{|c|}{ HANM-18 (L segment) } \\
\hline \multirow[t]{3}{*}{$1-528$} & $F(L 1-528)$ & TCTCAAAGAYATCAATCCCC \\
\hline & $\mathrm{R}(\mathrm{L} 1-528 \mathrm{~N})$ & AATGTGTTTGTCCAGAATGC \\
\hline & $\mathrm{R}(\mathrm{L} 1-528 \mathrm{~W})$ & TTGCAATTGAACATGCAGTC \\
\hline \multirow[t]{3}{*}{$412-2079$} & $\mathrm{~F}(\mathrm{~L}$ 412-2079) & TAYTTYGAGATTGTGCGGCAGCC \\
\hline & $\mathrm{R}(\mathrm{L} 412-2079 \mathrm{~N})$ & AACTCTGGATGYARYTGRGTTCG \\
\hline & $\mathrm{R}(\mathrm{L} 412-2079 \mathrm{~W})$ & GYACTGCYTCYACAGAYTCAGGC \\
\hline \multirow[t]{4}{*}{$1950-2910$} & $\mathrm{~F}(\mathrm{~L}$ 1950-2910 W) & TTTGCTATAYTRCCTCCYGACTG \\
\hline & $\mathrm{F}(\mathrm{L} 1950-2910 \mathrm{~N})$ & GATGACATAAGAAACTCYCCAAC \\
\hline & $\mathrm{R}(\mathrm{L} 1950-2910 \mathrm{~W})$ & CTGYTCYAAACTRGYRGGCAGTG \\
\hline & $\mathrm{R}(\mathrm{L} 1950-2910 \mathrm{~N})$ & CACCYTCRACYARTCCTTTDCGC \\
\hline \multirow[t]{4}{*}{$2997-3968$} & $\mathrm{~F}(\mathrm{~L} 2997-3968 \mathrm{~W})$ & AGYTACYTAAARGCAGGRACTGC \\
\hline & $\mathrm{F}(\mathrm{L} 2997-3968 \mathrm{~N})$ & TTRGARCAGGCWATGCGHAAAGG \\
\hline & $\mathrm{R}(\mathrm{L} 2997-3968 \mathrm{~W})$ & TTCATRCAYTCWGCTGCCACTTC \\
\hline & $\mathrm{R}(\mathrm{L} 2997-3968 \mathrm{~N})$ & AGAARGGTCCTTGYAAGAGYTCC \\
\hline \multirow[t]{4}{*}{$3820-5361$} & $F(L 3820-5361 \mathrm{~W})$ & AAGTGYTCTGTGCCAAGRTCTTG \\
\hline & $F(L 3820-5361 \mathrm{~N})$ & YTRTTTGACYTRAAGGTGCCCAC \\
\hline & $\mathrm{R}(\mathrm{L} 3820-5361 \mathrm{~W})$ & GTTTYTTTAGCTTMCCTCGAAGC \\
\hline & $\mathrm{R}(\mathrm{L} 3820-5361 \mathrm{~N})$ & ATCATRTGAGTTYTVGGTGATGC \\
\hline \multirow[t]{4}{*}{$5293-7371$} & $\mathrm{~F}(\mathrm{~L}$ 5293-7371 W) & AAACCATTYGAAYTAAGGTCAGG \\
\hline & $\mathrm{F}(\mathrm{L}$ 5293-7371 N $)$ & AARAAYCCYAGCCACACAATGGG \\
\hline & $\mathrm{R}(\mathrm{L}$ 5293-7371 N) & TCTTCACTRTRYTGCTCTACACC \\
\hline & R(L 5293-7371 W) & CTTRACTGTGTCRTTYCCRTCCC \\
\hline \multirow[t]{4}{*}{$7196-9253$} & F(L 7196-9253 W) & TCRGGTGAYAAYACCAARTGGGG \\
\hline & $\mathrm{F}(\mathrm{L} 7196-9253 \mathrm{~N})$ & YTTYTCHGGCATGATGCARCAGG \\
\hline & $\mathrm{R}(\mathrm{L} 7196-9253 \mathrm{~N})$ & CYCTYAGRCCRTCYTCAAATGTG \\
\hline & $\mathrm{R}(\mathrm{L} 7196-9253 \mathrm{~W})$ & CTCYARCTCAGATTCYGCAGGTC \\
\hline \multirow[t]{4}{*}{$9075-11103$} & F(L 9075-11103 W) & CRAACTAYCGTGAYAGTTGYGGC \\
\hline & $F(L 9075-11103 \mathrm{~N})$ & CYTTYCTRRGCTGYTCKGTYTCC \\
\hline & $R(L$ 9075-11103 N) & ACATTGTTRAAGCCTATGTCTTC \\
\hline & $\mathrm{R}(\mathrm{L}$ 9075-11103 W) & TCACTTTTCACTGTGTTTCTGTC \\
\hline \multirow[t]{3}{*}{$10690-12155$} & $\mathrm{~F}(\mathrm{~L} 10690-12155 \mathrm{~W})$ & GACACCCAAACCACATATC \\
\hline & $\mathrm{F}(\mathrm{L} 10690-12155 \mathrm{~N})$ & AAACGGAGCTTCTCCTTAAC \\
\hline & $\mathrm{R}(\mathrm{L}$ 10690-12155 ) & TCTCAAAGAAATCGTTCCCC \\
\hline \multicolumn{3}{|c|}{ HANM-18 (M segment) } \\
\hline \multirow[t]{3}{*}{$1-1395$} & F(M 1-1395) & TCTCAAAGAAATACTTGCGG \\
\hline & $\mathrm{R}(\mathrm{M} 1-1395 \mathrm{~N})$ & AATTAATGCGTGGCAGTTTG \\
\hline & R(M 1-1395 W) & AAACCTTGCCTGCATTTAAC \\
\hline $306-2128$ & $\mathrm{~F}(\mathrm{M} \mathrm{306-2128} \mathrm{W)}$ & AATACTTGCGGCACGTCAGTACG \\
\hline
\end{tabular}




\begin{tabular}{|c|c|c|}
\hline \multirow{7}{*}{ 1984-3871 } & $\mathrm{F}(\mathrm{M} 306-2128 \mathrm{~N})$ & MAGYGRAYYAGARGGCTCRGGAG \\
\hline & $\mathrm{R}(\mathrm{M} 306-2128 \mathrm{~N})$ & AGCTRAACCARAARAGRAARGCC \\
\hline & $\mathrm{R}(\mathrm{M} 306-2128 \mathrm{~W})$ & CCYCARACCTGCACCATATGTGA \\
\hline & F(M 1984-3871 W) & CTWTGCGAAAAYAGYGCCACAGG \\
\hline & $\mathrm{F}(\mathrm{M} 1984-3871 \mathrm{~N})$ & AATCACYCARGARGGRAGGGGCC \\
\hline & $\mathrm{R}(\mathrm{M} 1984-3871 \mathrm{~N})$ & RTGTGATWATYTCWGGAGGGAGC \\
\hline & R(M 1984-3871 W) & RTCTCCTGGYAYACCATGTGTGC \\
\hline \multirow[t]{3}{*}{$3732-4955$} & $\mathrm{~F}(\mathrm{M}$ 3732-4955 W) & TGYAAYCCYACTTGGTGYTGGGG \\
\hline & F(M 3732-4955 N) & CARTGYAGYYTGATTGARGCRGG \\
\hline & R(M 3732-4955 ) & CATCGTCYTTGAGGTGTCTRTAC \\
\hline \multirow[t]{3}{*}{ 4955-5368 } & F(M 4955-5368 W) & AGAGAGAGAATACTGCAAGAG \\
\hline & $\mathrm{F}(\mathrm{M} 4955-5368 \mathrm{~N})$ & TGGCTAGAGTCAATCAAGAG \\
\hline & $\mathrm{R}(\mathrm{M} 4955-5368)$ & TCTCAAAGATATAGTGGCGG \\
\hline \multirow[t]{3}{*}{$\begin{array}{l}\text { Н Алтм } 18 \\
1-549\end{array}$} & $\mathrm{~F}(\mathrm{~S} 1-549)$ & TCTCAAAGAAACACGTGCCGCTC \\
\hline & R(S 1-549 N) & TATCTGACAGCATTTCTTTGACGG \\
\hline & R(S 1-549 W) & TGGGTTTTCATCGCCACCTCTGT \\
\hline \multirow[t]{2}{*}{$290-545$} & F(S 290-545) & CATGGATCCTCTCAAAGAAACACGTGCC \\
\hline & R(S 290-545) & CTAACTGCAGTCTCAAAGATATCGTT \\
\hline \multirow[t]{3}{*}{ 367-1673 } & $\mathrm{F}(\mathrm{S} 367-1673 \mathrm{~W})$ & TTCGAAAAAAATGCAGGAATCATTAAA \\
\hline & $\mathrm{F}(\mathrm{S} 367-1673 \mathrm{~N})$ & TCCATCTACGCATCAGCTCTGGTGGA \\
\hline & $\mathrm{R}(\mathrm{S} 367-1673)$ & TCTCAAAGATATCGTTGCCGCACAG \\
\hline
\end{tabular}


Table S2. Comparison of nucleotide sequence identity with other CCHFV strains' S segment

\begin{tabular}{|c|c|c|c|}
\hline \multirow[t]{2}{*}{ Strain } & \multirow[t]{2}{*}{ County } & \multirow{2}{*}{$\begin{array}{c}\text { GenBank accession } \\
\text { number }\end{array}$} & $\begin{array}{c}\text { S segment of } \\
\text { HANM-18 }\end{array}$ \\
\hline & & & nt $(\%)$ \\
\hline 75024 & China & AF362080 & 95.1 \\
\hline 7001 & China & AF415236 & 93.3 \\
\hline $9553 / 2001$ & Kosovo & AF428144 & 88.6 \\
\hline Uzbek/TI10145 & Uzbekistan & AF481799 & 94.7 \\
\hline STV/HU29223 & Russia & AF481802 & 89.4 \\
\hline Matin & Pakistan & AF527810 & 89.9 \\
\hline 66019 & China & AJ010648 & 95.2 \\
\hline 8402 & China & AJ010649 & 94.7 \\
\hline Baghdad 12 & Iraq & AJ538196 & 89.5 \\
\hline Pakistan & Pakistan & AJ538198 & 89.8 \\
\hline 88166 & China & AY029157 & 94.9 \\
\hline TAJ/HU8966 & Tajikistan & AY049083 & 93.0 \\
\hline Hodzha & Uzbekistan & AY223475 & 93.1 \\
\hline ROS/TI28044 & Russia & AY277672 & 88.1 \\
\hline Bul/HU517 & Bulgaria & AY277676 & 87.9 \\
\hline TAJ/HU8975 & Tajikistan & AY297692 & 95.5 \\
\hline Semunya & Uganda & DQ076413 & 81.7 \\
\hline SPU128/81/7 & South Africa & DQ076415 & 87.6 \\
\hline SPU4/81 & South Africa & DQ076416 & 87.9 \\
\hline Hoti & Kosovo & DQ133507 & 88.6 \\
\hline ROS/HUVLV-100 & Russia & DQ206447 & 88.2 \\
\hline AP92 & Greece & DQ211638 & 82.0 \\
\hline ArD8194 & Senegal & DQ211639 & 83.1 \\
\hline ArD15786 & Senegal & DQ211640 & 83.1 \\
\hline ArD39554 & Mauritania & DQ211641 & 87.3 \\
\hline C-68031 & China & DQ211642 & 95.1 \\
\hline Drosdov & Russia & DQ211643 & 87.9 \\
\hline Kashmanov & Russia & DQ211644 & 88.2 \\
\hline Oman & Oman & DQ211645 & 89.8 \\
\hline SPU97/85 & South Africa & DQ211646 & 87.3 \\
\hline SPU103/87 & South Africa & DQ211647 & 87.7 \\
\hline SPU415/85 & South Africa & DQ211648 & 87.6 \\
\hline Turkey200310849 & Turkey & DQ211649 & 88.0 \\
\hline UG3010 & Congo & DQ211650 & 85.3 \\
\hline CYL/TI05035 & China & DQ217602 & 93.4 \\
\hline CYT/TI05099 & China & DQ227495 & 93.6 \\
\hline Iran-52 & Iran & DQ446212 & 88.3 \\
\hline Iran-53 & Iran & DQ446213 & 88.3 \\
\hline Iran-56 & Iran & DQ446214 & 88.2 \\
\hline 66/08-Rodopi & Greece & EU871766 & 87.8 \\
\hline YL04057 & China & FJ562093 & 93.9 \\
\hline Turkey-Kelkit06 & Turkey & GQ337053 & 87.7 \\
\hline Sudan_Al-Fulah_3-2008 & Sudan & GQ862371 & 87.6 \\
\hline Sudan_Al-Fulah_4-2008 & Sudan & GQ862372 & 87.6 \\
\hline $\mathrm{V} 42 / 81$ & Bulgaria & GU477489 & 88.0 \\
\hline 79121M18 & China & GU477494 & 93.4 \\
\hline Afg09-2990 & Afghanistan & HM452305 & 90.0 \\
\hline Sudan_AB1-2009 & Sudan & HQ378179 & 85.8 \\
\hline Beruwe 2008 & Congo & HQ849545 & 77.2 \\
\hline NIV_1040532 & India & JF922679 & 90.8 \\
\hline NIV_10405051 & India & JF922681 & 91.3 \\
\hline
\end{tabular}




\begin{tabular}{|c|c|c|c|}
\hline TAJUK_*7 & Tajikistan & JN086996 & 82.6 \\
\hline Dubai_616 & United Arab Emirates & JN108025 & 82.2 \\
\hline NIVA_118594 & India & JN572087 & 92.5 \\
\hline NIV_112143 & India & JN572089 & 92.0 \\
\hline HSADL & India & JX051650 & 93.0 \\
\hline SCT & Afghanistan & JX908640 & 89.7 \\
\hline Zahedan & Iran & KC867274 & 90.3 \\
\hline Iran-Gilan69 & Iran & KJ027521 & 89.7 \\
\hline Iran-Isfahan78 & Iran & KJ027522 & 88.1 \\
\hline Iran-Kerman43 & Iran & KJ196326 & 90.1 \\
\hline Iran-Zahedan19 & Iran & KJ676542 & 93.2 \\
\hline SPU_431/85 & South Africa & KJ682815 & 87.6 \\
\hline SPU_383/87 & South Africa & KJ682816 & 87.9 \\
\hline SPU_556/87 & South Africa & KJ682817 & 87.2 \\
\hline SPU_18/88 & South Africa & KJ682818 & 87.3 \\
\hline SPU_45/88 & South Africa & KJ682819 & 87.1 \\
\hline SPU_497/88 & South Africa & KJ682820 & 87.2 \\
\hline SPU_130/89 & South Africa & KJ682821 & 87.8 \\
\hline SPU_48/90 & South Africa & KJ682822 & 87.1 \\
\hline SPU_187/90 & South Africa & KJ682823 & 87.5 \\
\hline SPU_44/08 & South Africa & KJ682824 & 87.0 \\
\hline 59-TK-2012 & Russia & KR814833 & 79.0 \\
\hline 128-TK-2012 & Russia & KR814834 & 79.0 \\
\hline 37-ST-2009 & Russia & KR814835 & 79.2 \\
\hline 73-ST-2013 & Russia & KR814836 & 85.4 \\
\hline 24-R-2012 & Russia & KR814837 & 87.8 \\
\hline 36-ST-2014 & Russia & KR814838 & 87.9 \\
\hline 37-R-2013 & Russia & KR814839 & 87.8 \\
\hline 44-ST-2010 & Russia & KR814840 & 88.0 \\
\hline 46-ST-2012 & Russia & KR814841 & 88.2 \\
\hline 47-ST-2013 & Russia & KR814842 & 88.2 \\
\hline 52-R-2014 & Russia & KR814843 & 87.9 \\
\hline 75-R-2012 & Russia & KR814844 & 88.2 \\
\hline 75-ST-2010 & Russia & KR814845 & 88.0 \\
\hline 81-R-2014 & Russia & KR814846 & 87.9 \\
\hline 3756-ST-2007 & Russia & KR814847 & 85.9 \\
\hline 3809-ST-2007 & Russia & KR814848 & 88.0 \\
\hline 3820-ST-2007 & Russia & KR814849 & 87.9 \\
\hline 4495-ST-2008 & Russia & KR814850 & 86.0 \\
\hline 4574-ST-2008 & Russia & KR814851 & 88.0 \\
\hline 4691-ST-2009 & Russia & KR814852 & 87.9 \\
\hline 4701-ST-2009 & Russia & KR814853 & 87.9 \\
\hline 5170-R-2011 & Russia & KR814854 & 87.7 \\
\hline 5180-R-2011 & Russia & KR814855 & 87.8 \\
\hline $\mathrm{CHH}$ & Iran & KU707898 & 90.2 \\
\hline GRH & Iran & KU707900 & 90.3 \\
\hline SRR & Iran & KU707901 & 92.8 \\
\hline Gaib & Tajikistan & KX013446 & 91.6 \\
\hline Hodzha & Uzbekistan & KX013449 & 90.9 \\
\hline K128_76 & Kazakhstan & KX013455 & 93.1 \\
\hline K168_40 & Turkmenistan & KX013458 & 91.4 \\
\hline K168_125 & Turkmenistan & KX013461 & 90.7 \\
\hline SK_2015/human & Kazakhstan & KX129738 & 88.1 \\
\hline YL16070 & China & KY354080 & 93.5 \\
\hline WJQ16206 & China & MG659724 & 88.9 \\
\hline FK16116 & China & MG659727 & 81.6 \\
\hline
\end{tabular}




\begin{tabular}{|c|c|c|c|}
\hline Oman_2012-40S & Oman & MH037279 & 90.2 \\
\hline Oman_2013-116S & Oman & MH037280 & 90.4 \\
\hline Oman_2014-828P & Oman & MH037281 & 90.2 \\
\hline 2013_16_44 & Kosovo & MH133289 & 88.8 \\
\hline 2013_22_319 & Kosovo & MH133298 & 88.8 \\
\hline 2014-C-K14-1C & Kosovo & MH133307 & 88.9 \\
\hline NIV1733666 & India & MN135942 & M5.4 \\
\hline 61T & Pakistan & MN866192 & 93.3 \\
\hline MCL-19-T-1812 & India & MN930427 & 93.3 \\
\hline 19-H-3075 & India & MN930428 & 93.3 \\
\hline 19-H-3068 & India & MN930429 & 93.0 \\
\hline 19-H-3081 & India & U88416 & 85.0 \\
\hline UGANDA_3010 & Ugadan & & \\
\hline
\end{tabular}


Table S3. Comparison of amino acid and nucleotide sequence identity with other CCHFV strains' M segment

\begin{tabular}{|c|c|c|c|c|}
\hline \multirow[t]{2}{*}{ Strain } & \multirow[t]{2}{*}{ Country } & \multirow{2}{*}{$\begin{array}{c}\text { GenBank } \\
\text { accession number }\end{array}$} & \multicolumn{2}{|c|}{$\begin{array}{l}\text { M segment of } \\
\text { HANM-18 }\end{array}$} \\
\hline & & & nt (\%) & aa $(\%)$ \\
\hline 66019 & China & AB069669 & 84.4 & 87.4 \\
\hline 7001 & China & AB069670 & 69.8 & 72.6 \\
\hline 75024 & China & AB069671 & 81.2 & 85.7 \\
\hline 7803 & China & AB069672 & 80.9 & 85.5 \\
\hline 79121 & China & AB069673 & 69.7 & 72.3 \\
\hline 8402 & China & AB069674 & 87.5 & 89.3 \\
\hline 88166 & China & AB069675 & 87.5 & 89.4 \\
\hline BA88166 & China & AF338470 & 87.4 & 89.4 \\
\hline BA66019 & China & AF350448 & 84.3 & 87.4 \\
\hline BA8402 & China & AF350449 & 87.2 & 88.7 \\
\hline IbAr10200 & Nigeria & AF467768 & 81.5 & 85.1 \\
\hline Matin & Pakistan & AF467769 & 87.8 & 90.1 \\
\hline Baghdad 12 & Iraq & AJ538197 & 81.0 & 85.8 \\
\hline Pakistan & Pakistan & AJ538199 & 80.5 & 84.1 \\
\hline VLG/TI29414 & Russia & AY179961 & 80.5 & 84.2 \\
\hline TADJ/HU8966 & Tajikistan & AY179962 & 80.0 & 84.4 \\
\hline Hodzha & Uzbekistan & AY223476 & 81.1 & 85.2 \\
\hline Kosovo/9553/2001 & Yugoslavia & AY675511 & 80.9 & 84.4 \\
\hline 3010 & Congo & DQ019222 & 68.0 & 72.3 \\
\hline Semunya & Uganda & DQ094832 & 67.7 & 71.6 \\
\hline SPU128/81/7 & South Africa & DQ157174 & 81.5 & 85.7 \\
\hline SPU4/81 & South Africa & DQ157175 & 81.6 & 85.7 \\
\hline ROS/HUVLV-100 & Russia & DQ206448 & 81.5 & 84.8 \\
\hline AP92 & Greece & DQ211625 & 70.3 & 72.8 \\
\hline ArD8194 & Senegal & DQ211626 & 67.9 & 72.5 \\
\hline ArD15786 & Senegal & DQ211627 & 67.8 & 72.4 \\
\hline ArD39554 & Mauritania & DQ211628 & 70.5 & 76.5 \\
\hline C-68031 & China & DQ211629 & 87.6 & 89.4 \\
\hline Drosdov & Russia & DQ211630 & 81.2 & 84.0 \\
\hline Kashmanov & Russia & DQ211631 & 81.7 & 84.7 \\
\hline Oman & Oman & DQ211632 & 86.7 & 89.7 \\
\hline SPU97/85 & South Africa & DQ211633 & 91.1 & 91.9 \\
\hline SPU103/87 & South Africa & DQ211634 & 80.8 & 84.4 \\
\hline SPU415/85 & South Africa & DQ211635 & 91.1 & 91.9 \\
\hline Turkey200310849 & Turkey & DQ211636 & 81.7 & 84.3 \\
\hline UG3010 & Congo & DQ211637 & 68.0 & 72.3 \\
\hline Iran-52 & Iran & DQ446215 & 79.6 & 84.9 \\
\hline Iran-53 & Iran & DQ446216 & 80.8 & 84.8 \\
\hline Kosova Hoti & Yugoslavia & EU037902 & 81.7 & 84.6 \\
\hline YL04057 & China & FJ562094 & 69.7 & 72.5 \\
\hline Turkey-Kelkit06 & Turkey & GQ337054 & 81.6 & 83.8 \\
\hline V42/81 & Bulgaria & GU477490 & 80.8 & 83.5 \\
\hline $79121 \mathrm{M} 18$ & China & GU477493 & 69.8 & 72.4 \\
\hline Afg09-2990 & Afghanistan & HM452306 & 80.9 & 84.8 \\
\hline Al-Fulah 3-2008 & Sudan & HQ378184 & 80.8 & 85.1 \\
\hline Al-Fulah 9-2008 & Sudan & HQ378185 & 80.8 & 85.1 \\
\hline AB1-2009 & Sudan & HQ378187 & 81.1 & 85.2 \\
\hline NIVA118594 & India & JN572084 & 81.4 & 85.2 \\
\hline NIV112143 & India & JN572085 & 81.4 & 85.2 \\
\hline NIV11703 & India & JN572086 & 81.5 & 85.2 \\
\hline SCT ex Afghanistan & Afghanistan & KC344856 & 83.6 & 86.2 \\
\hline Zahedan & Iran & KC867273 & 80.8 & 84.8 \\
\hline SPU44/08 & South Africa & KJ682805 & 86.1 & 88.7 \\
\hline SPU130/89 & South Africa & KJ682807 & 85.9 & 88.2 \\
\hline
\end{tabular}




\begin{tabular}{|c|c|c|c|c|}
\hline SPU45/88 & South Africa & KJ682809 & 86.5 & 87.9 \\
\hline SPU18/88 & South Africa & KJ682810 & 86.1 & 88.4 \\
\hline SPU556/87 & South Africa & KJ682811 & 91.1 & 91.8 \\
\hline SPU431/85 & South Africa & KJ682812 & 90.8 & 91.9 \\
\hline SPU48/90 & South Africa & KJ682813 & 81.3 & 85.2 \\
\hline SPU187/90 & South Africa & KJ682814 & 81.3 & 85.7 \\
\hline Haskovo-V46/13 & Bulgaria & KR092379 & 81.4 & 84.2 \\
\hline 24-R-2012 & Russia & KR814856 & 81.7 & 84.8 \\
\hline 37-R-2013 & Russia & KR814858 & 81.6 & 84.7 \\
\hline 46-ST-2012 & Russia & KR814860 & 81.5 & 85.0 \\
\hline 52-R-2014 & Russia & KR814862 & 81.6 & 84.6 \\
\hline 75-R-2012 & Russia & KR814863 & 81.5 & 84.5 \\
\hline 75-ST-2010 & Russia & KR814864 & 81.7 & 84.9 \\
\hline 3809-ST-2007 & Russia & KR814867 & 81.6 & 84.6 \\
\hline 4495-ST-2008 & Russia & KR814869 & 81.4 & 84.9 \\
\hline 4574-ST-2008 & Russia & KR814870 & 81.7 & 84.8 \\
\hline 4691-ST-2009 & Russia & KR814871 & 81.1 & 84.4 \\
\hline 5180-R-2011 & Russia & KR814874 & 81.6 & 84.7 \\
\hline Oman-199809166 & Oman & KR864901 & 86.7 & 89.5 \\
\hline 1-CR/HU-2015 & Russia & KU161584 & 81.1 & 84.2 \\
\hline Gaib & Tajikistan & KX013445 & 83.1 & 87.2 \\
\hline K128_76 & Kazakhstan & KX013454 & 80.8 & 85.7 \\
\hline K168_40 & Turkmenistan & KX013457 & 80.9 & 85.7 \\
\hline K168_125 & Turkmenistan & KX013460 & 80.8 & 85.5 \\
\hline K229_243 & Russia & KX013466 & 81.2 & 84.7 \\
\hline Min & Russia & KX013481 & 81.2 & 84.7 \\
\hline Saf & Russia & KX013487 & 81.1 & 84.8 \\
\hline Ast133 & Russia & KX056060 & 81.1 & 84.6 \\
\hline YL16070 & China & KY354081 & 69.6 & 72.3 \\
\hline Oman_812956 & Oman & KY362518 & 86.7 & 89.5 \\
\hline UCCR4405 & Russia & KY484029 & 81.2 & 84.1 \\
\hline UCCR4459 & China & KY484032 & 87.5 & 89.4 \\
\hline UCCR4401 & Nigeria & KY484035 & 81.6 & 85.2 \\
\hline UCCR4448 & South Africa & KY484042 & 81.6 & 85.6 \\
\hline UCCR4417 & Uganda & KY484045 & 81.6 & 85.7 \\
\hline Tur_2004_813139 & Turkey & MF511227 & 81.6 & 84.5 \\
\hline Tur_2004_813151 & Turkey & MF511233 & 81.4 & 84.4 \\
\hline SPUD8_81_7_813051 & South Africa & MF511236 & 81.2 & 85.7 \\
\hline 2013_6_180 & Kosovo & MH133278 & 81.3 & 84.7 \\
\hline 2013_14_79 & Kosovo & MH133287 & 81.7 & 84.5 \\
\hline 2014-C-K14-1C & Kosovo & MH133308 & 81.0 & 84.5 \\
\hline 2015-A-K15-1A & Kosovo & MH133311 & 81.2 & 84.4 \\
\hline NIV1311122 & India & MH396643 & 81.2 & 85.2 \\
\hline NIV149247 & India & MH396650 & 81.2 & 85.0 \\
\hline NIV1511559 & India & MH396656 & 80.8 & 85.0 \\
\hline NIV164392 & India & MH396662 & 81.3 & 85.1 \\
\hline 61T/Pakistan & Pakistan & MN135943 & 80.6 & 84.7 \\
\hline 19-H-3116 & India & MN930412 & 80.7 & 85.0 \\
\hline
\end{tabular}


Table S4. Comparison of nucleotide sequence identity with other CCHFV strains' L segment

\begin{tabular}{|c|c|c|c|}
\hline \multirow[t]{2}{*}{ Strain } & \multirow[t]{2}{*}{ County } & \multirow{2}{*}{$\begin{array}{c}\text { GenBank accession } \\
\text { number }\end{array}$} & $\begin{array}{c}\text { L segment of } \\
\text { HANM-18 }\end{array}$ \\
\hline & & & nt $(\%)$ \\
\hline Matin & Pakistan & AY422208 & 87.3 \\
\hline TADJ/HU8966 & Tajikistan & AY720893 & 87.4 \\
\hline Baghdad-12 & Iraq & AY947890 & 87.4 \\
\hline IbAr10200 & Nigeria & AY947891 & 86.8 \\
\hline VLV-100 & Russia & AY995166 & 87.4 \\
\hline Semunya & Uganda & DQ076412 & 82.3 \\
\hline 3010 & Congo & DQ099335 & 83.4 \\
\hline AP92 & Greece & DQ211612 & 77.7 \\
\hline ArD8194 & Senegal & DQ211613 & 86.9 \\
\hline ArD15786 & Senegal & DQ211614 & 86.7 \\
\hline ArD39554 & Mauritania & DQ211615 & 86.7 \\
\hline C-68031 & China & DQ211616 & 87.5 \\
\hline Drosdov & Russia & DQ211617 & 87.9 \\
\hline Kashmanov & Russia & DQ211618 & 87.6 \\
\hline Oman & Oman & DQ211619 & 86.5 \\
\hline SPU103/87 & South Africa & DQ211621 & 87.3 \\
\hline SPU415/85 & South Africa & DQ211622 & 87.2 \\
\hline 10849 & Turkey & DQ211623 & 87.9 \\
\hline UG3010 & Congo & DQ211624 & 83.4 \\
\hline Kosova_Hoti & Yugoslavia & EU044832 & 87.9 \\
\hline YL04057 & China & FJ562095 & 93.7 \\
\hline Kelkit06 & Turkey & GQ337055 & 87.8 \\
\hline $79121 \mathrm{M} 18$ & China & GU477492 & 93.7 \\
\hline _Afg09-2990 & Afghanistan & HM452307 & 87.2 \\
\hline Al-Fulah_3 & Sudan & HQ378180 & 86.5 \\
\hline Al-Fulah_4 & Sudan & HQ378181 & 86.5 \\
\hline Al-Fulah_9 & Sudan & HQ378182 & 86.5 \\
\hline $\mathrm{AB} 1$ & Sudan & HQ378183 & 86.7 \\
\hline NIVA118595 & India & JN572090 & 86.9 \\
\hline NIV112143 & India & JN572091 & 87.0 \\
\hline SCT_ex_Afghanistan & Afghanistan & КC344855 & 87.3 \\
\hline Zahedan & Iran & KC867272 & 87.1 \\
\hline SPU187/90 & South Africa & KJ682795 & 87.3 \\
\hline SPU48/90 & South Africa & KJ682797 & 86.7 \\
\hline SPU431/85 & South Africa & KJ682799 & 87.0 \\
\hline SPU383/87 & South Africa & KJ682801 & 87.0 \\
\hline SPU18/88 & South Africa & KJ682803 & 87.2 \\
\hline SPU497/88 & Namibia & KJ682804 & 87.0 \\
\hline 36-ST & Russia & KR814876 & 87.7 \\
\hline
\end{tabular}




\begin{tabular}{|c|c|c|c|}
\hline $37-\mathrm{R}$ & Russia & KR814877 & 87.5 \\
\hline $44-\mathrm{ST}$ & Russia & KR814878 & 87.7 \\
\hline $46-\mathrm{ST}$ & Russia & KR814879 & 87.7 \\
\hline $3820-\mathrm{ST}$ & Russia & KR814887 & 87.6 \\
\hline 4691-ST & Russia & KR814890 & 87.7 \\
\hline $1-\mathrm{CR} / \mathrm{HU}$ & Russia & KU161582 & 87.5 \\
\hline 1231-CR/TI-2015 & Russia & KU161583 & 87.7 \\
\hline Gaib & Tajikistan & KX013444 & 87.3 \\
\hline Hodzha & Uzbekistan & KX013447 & 87.3 \\
\hline K168_40 & Turkmenistan & KX013456 & 87.3 \\
\hline K229_194 & Russia & KX013462 & 87.5 \\
\hline K229_243 & Russia & KX013465 & 87.5 \\
\hline K315_14 & Russia & KX013468 & 87.4 \\
\hline Mamon & Russia & KX013477 & 87.3 \\
\hline Saf & Russia & KX013486 & 87.6 \\
\hline Ast199 & Russia & KX056050 & 87.3 \\
\hline Ast149 & Russia & KX056053 & 87.6 \\
\hline Ast133 & Russia & KX056059 & 87.7 \\
\hline NIV161064 & India & KY213712 & 86.9 \\
\hline YL16070 & China & KY354082 & 93.7 \\
\hline UCCR4413 & Pakistan & KY484039 & 87.2 \\
\hline UCCR4417 & Uganda & KY484043 & 87.2 \\
\hline Kalmykia_Shch_1 & Russia & KY982864 & 87.4 \\
\hline Tur_2004_813048 & Turkey & MF511190 & 87.9 \\
\hline Tur_2004_813135 & Turkey & MF511191 & 87.7 \\
\hline Tur_2004_813137 & Turkey & MF511192 & 87.8 \\
\hline SPU41_84_813060 & South Africa & MF511206 & 86.5 \\
\hline 2013_6_180 & Kosovo & MH133279 & 88.1 \\
\hline 2013_14_79 & Kosovo & MH133288 & 88.0 \\
\hline 2013_19_289 & Kosovo & MH133297 & 88.0 \\
\hline 2013_25_380 & Kosovo & MH133303 & 87.9 \\
\hline A-K14-1A & Kosovo & MH133306 & 87.7 \\
\hline A-K15-1A & Kosovo & MH133312 & 87.6 \\
\hline NIV1733666 & India & MH396673 & 87.0 \\
\hline YL16204 & China & MH688499 & 93.7 \\
\hline MCL-18-T-305 & India & MK330136 & 87.2 \\
\hline 19-H-3068 & India & MN930403 & 87.1 \\
\hline 19-H-2856 & India & MN930405 & 87.2 \\
\hline 19-H-3092 & India & MN930408 & 87.2 \\
\hline 19-T-1989 & India & MN930410 & 87.1 \\
\hline
\end{tabular}

